\title{
Building Competitive Advantage Through Innovative Reverse Logistics Capabilities
}

\author{
Ju-Miao Melody Hsiao \\ Department of Marketing and Logistics Management, Ling Tung University, \\ 1 Ling Tung Road, Nantun District, Taichung 408, Taiwan \\ E-mail: melodyh@teamail.ltu.edu.tw
}

\begin{abstract}
The recent global economic recession has forced many business firms to increase efficiency, cut waste and invest in innovation in order to sustain competitiveness. The purpose of this study is to explore how firms handle their returns processes, an area which can impact on competitive advantage. The research focuses on short life-cycle products. The study used case study methodology, conducting in-depth interviews with key logistics managers in four companies. The findings revealed that, although each company had different emphasis in handling product returns, three key drivers, namely information technology, knowledge sharing and relationship networks, had positive impacts on its reverse logistics capabilities and consequently on their competitive advantage.
\end{abstract}

Keywords: : service innovation, short life-cycle product, reverse logistics capabilities, competitive advantage

\section{Introduction}

Since September 2008, the global financial crisis has drastically impacted the economies of most countries around the world. To transform the crisis into an opportunity in order to survive, increasing efficiency, cutting waste and investing in innovation has become crucial for firms to sustain competitiveness (Goffin and Perkins, 2009). Product returns occur in almost every industry. Reverse logistics costs accounted for approximately four percent (roughly US $\$ 40$ billion) of the total logistics costs in the United States and reduced firm profits up to 35 percent (Rogers and Tibben-Lembke, 2001). The economic recession presents a good time to examine firms' returns management and reverse logistics efficiency.

According to the Resource-Based View (RBV), firms compete on the basis of their resources and capabilities, and the distinctive capabilities of firms are the critical resources of sustained competitive advantage (Oliver, 1997). Resources (either tangible or intangible) are the inputs into a firm's value chain and have been viewed as the source of a firm's capability (Grant, 1991). Several studies proposed that logistics capabilities can positively affect firm performance (Fawcett et al. 1997; Yang et al. 2009; Zhao et al. 2001) or competitive advantage (Morash et al. 1996). Furthermore, Richey et al. (2005) claim that resources can be used to develop innovative reverse logistics capabilities to gain competitive differentiation and improve reverse logistics service efficiency. But, what are the key resources can be deployed? Although technology as the resource is frequently mentioned in the literature, knowledge sharing and relationship networks have been neglected as important elements driving service innovation and should be addressed in the literature as a proactive strategy in managing reverse logistics. Therefore, the objectives of this study are to (1) identify key factors that drive service innovation to enhance a firm's reverse logistics capabilities, and 
(2) investigate how a firm's reverse logistics capabilities affect its competitive advantage.

The following section provides a review of the relevant literature that underpins the background and theoretical foundation.

\section{Literature Review}

\subsection{Reverse Logistics and Reverse Logistic Capabilities}

Growing concerns about environmental issues, sustainable development and regulatory compliance have made organizations responsive to reverse logistics (Srivastava and Srivastava, 2006). According to Rogers and Tibben-Lembke (1999, p. 2), reverse logistics is defined as:

The process of planning, implementing and controlling the efficient, cost-effective flow of raw materials, in-process inventory, finished goods and related information from the point of consumption to the point of origin for the purpose of recapturing or creating value or for proper disposal.

Stock et al. (2002, p. 16) state that reverse logistics includes the remanufacturing, refurbishing, recycling, reuse, or disposal of goods.

In the RBV, logistics capability represents the ability of logistics providers to create and deploy resources to satisfy the logistics needs of their customers in pursuit of better service performance. Though admitting the importance of forward logistics, this study focuses on reverse logistics capabilities, specifically product returns. According to Jack et al. (2010, p.230), reverse logistics capabilities refer to "the internal capabilities and processes that the firm deploys to effectively implement its reverse logistics activities." The reverse logistics capabilities can contain the accuracy and the availability of information, the process and timeliness of reverse logistics information, the internal and external connectivity, usefulness of information (Jack et al., 2010), the ability to recover costs, and develop standardized processes and rules governing the return, repair and refurbishment of assets (Pollock, 2010).

Many companies have realized the returns process incurs significant costs. Returns processing costs involve collection and transportation of returns from the reseller to the upstream supplier or distribution center, inspection, sorting, repair, repackaging, and resale or disposal, and the costs can be as high as 30 35 percent of potential profits (Stuart et al., 2005). Autry et al. (2001) point out that an effective returns management should be regarded as a high priority in view of the increasing needs to accommodate damaged or defective merchandise, product recalls, maintenance and repairs, and recycling. Thus, the enhancement of reverse logistics capabilities can be considered as a potential source of competitive advantage.

\subsection{Key Enabling Factors for Service Innovation}

According to Kandampully (2002), service innovation is dependent on three key factors-technology, knowledge and relationship networks. Therefore, this study investigates whether information technology, knowledge sharing and relationship networks are the enabling factors for service innovation in the returns process, and whether they contribute to an improvement of a firm's reverse logistics capability. The three enabling factors are described in detail below:

\section{Information technology (IT)}

Technology plays an important role as a facilitating factor in supply chain management. IT refers to "the hardware, software, and network investment and design to facilitate processing and exchange" (Global Logistics Research Team at Michigan State University, 1995, p. 137). The evolving information technologies facilitate more timely and accurate information to reduce uncertainties in supply and demand, better synchronize supply with demand, and thereby improve coordination and financial performance. For example, Wal-Mart's collaboration with suppliers in applying FRID technology has significantly reduced out-of-stock items by $26 \%$ and achieved a faster replenishment rate that is three times the original replenishment rate for out-of-stock items (Richey et al., 2008). In addition, the adoption of intelligent decision support system helps to reduce the processing time in returns authorization and disposition. Richey et al. (2008) suggest that increases in the utilization of technology between the retailer and the supplier will improve the retailer's operational effectiveness. 


\section{Knowledge sharing}

In this competitive environment, knowledge is fundamental to innovation and becomes the strategic asset of a firm. Supplier collaboration facilitates the sharing of tacit and explicit knowledge and enhances knowledge creation and innovation implementation (Inkpen, 1996). Ganesan et al. (2009) suggest that the acquisition of knowledge from supply chain partners could enhance both radical and incremental innovations. Supply chain information identifying technology advancement and potential risks is also necessary for predictive insights.

Information about industry developments, market trends, competitive forces, and new products/ services should be shared between supply chain partners. The efficiency of reverse logistics can be improved in the process of product design by taking the requirements of the customer's post-use or postconsumption collection, sorting and recycling into consideration. Through knowledge management, a firm is able to create and distribute new, innovative products and processes to both decrease the returns and handle the returns efficiently and cost effectively. For example, by learning from the returns Black and Decker integrates the returns process with product development so that it can develop better, ease-ofuse products and minimize future returns.

\section{Relationship networks}

The key to successful supply chain management is seeking improved inter-organizational relationships that can enhance innovation (Soosay et al., 2008). To match supply with demand for goods and services, supply chain partners need to coordinate complementary capabilities within the relationship network. Competing more effectively in a fastchanging environment, where speed to undertake innovations and reaction to market changes are getting critical, will require buyer's and supplier's collaborative efforts throughout the supply chain.

Ganesan et al. (2009) argue that stronger ties between retailers and their supply chain partners may facilitate radical innovations. A diversity of supply chain partners can promote not only radical process and product innovations, but exchange and transfer of novel and valuable information. Swink (2006, p. 37) states that "the organization's ability to collaborate is key to its innovative success." Soosay et al. (2008) revealed that inter-organizational relationships contributed to knowledge creation capabilities in firms. Kahn, Maltz, and Mentzer (2006) suggest that collaboration fosters knowledge creation, and knowledge creation leads to innovation and longterm competitive advantage in the supply chain. Soosay et al. (2008) further point out that sharing information, joint planning, joint problem solving and joint decision-making are the key activities in the collaborative relationship network.

\subsection{Competitive Advantage}

Competitive advantage is broadly expressed in terms of cost, flexibility, quality and delivery (Kathuria, 2000). Michael Porter (1998) identifies two basic types of competitive strategies - cost advantage and differentiation advantage. For example, ccompetitive advantage is gained when a firm is able to provide the same benefits as its competitors but at a lower cost (cost advantage), or provide greater benefits that are superior to its competitors (differentiation advantage). Stock et al. (2002, p. 16) stress that "reverse logistics should not be viewed as a costly side-show to normal operations. Rather...[it] should be seen as an opportunity to build competitive advantage." Many successful companies have recognized that an effective product returns strategy or process can bring benefits for themselves as well as for their customers such as improved customer service and customer knowledge, reduced costs of environmental compliance or waste disposal, minimization of purchase risks, and a boost to goodwill by demonstrating good corporate citizenship (Molenkopf and Closs, 2005). Jayaraman and Luo (2007) report that tangible competitive advantages gained through reverse logistics capabilities include value recovery from used products, green products credibility and sales growth, whereas intangible competitive advantages include corporate image, customer satisfaction, and feedback information from product returns.

The RBV regards the enhancement of service capability as a potential source of competitive advantages. A good reverse logistics program can be a differentiator and offer a means of achieving market advantage (Stock, 2001). Richey et al. (2005) state that resources can be used to develop innovative reverse logistics capabilities in order to enhance performance and gain competitive differentiation. 


\section{Methodology}

This research aims to explore the returns process of short life-cycle products, and the relationships between reverse logistics capabilities, service innovations within the sector and competitive advantage. The study takes as its data the reverse logistics operations of some short life-cycle products in Taiwan. Because short life-cycle products are characterized by seasonality, and uncertainty and variability in customer demand, innovative solutions to the returns management and reverse logistics capabilities are particularly imperative in today's competitive markets. As the case study method is an exploratory and descriptive approach that allows in-depth insights into the research object (Yin, 1994), the case study method was used for this study.

The logistics manager or warehouse manager dealing with reverse logistics management was considered to be the most appropriate respondent. Four field interviews were conducted with four logistics or warehouse managers from four industries, namely food products, sports footwear, sports apparel and book publishing in Taiwan. Open-ended questions were used so that the respondents were able to freely express their views and experiences with respect to their returns processing and reverse logistics capabilities of their organization.

Eight questions were asked in the in-depth interview. Six of these were relevant to "reverse logistics capabilities". They were (1)reasons for returns, (2)average percentage of product return, (3)cycle time of returns processing, (4)process of handling returns, (5)guidelines for returns avoidance and gatekeeping, and (6)disposition of defective returns. The other two questions were (7)initiatives of innovative service in information technology, knowledge sharing, and relationship networks, and (8)competitive advantage with respect to reverse logistics capabilities.

\section{Company Background}

The background of the four case companies is briefly described as follows:

\section{IM Company}

IM has been a manufacturer, distributor, importer and exporter of quality food products in Taiwan since 1934. Its product lines include confectioneries and sweets, frozen desserts, frozen prepared foods and gift packs. Except exporting food product to many countries worldwide, IM sells food products through multichannels such as own chain stores, local distributors, hyper markets, supermarkets, conventional retail stores and convenience stores. Quality and management are the key success factors that make IM become one of the major suppliers of several famous international retailers and fast food companies in Taiwan such as McDonald, Burger King, and Kentucky Fried Chicken (KFC).

\section{UD Company}

UD Company was established in 1979 and is the largest distributor in the publishing industry in Taiwan. It sells and distributes books and magazines for more than 500 local publishers and some Japanese publishers to over 2,000 bookstores in Taiwan. UD's logistics center is equipped with several leading-edge logistics facilities such as automatic sorting system and check weight system. It provides logistics services not only for its retailers, but also for some large publishing firms as a 3PL service provider.

\section{AR Group}

AR Group has been engaged in manufacturing and distributing various kinds of sports footwear, apparel, bags and other sports-related accessories since 1989. AR's management philosophy emphasizes integrity, communication, service, innovation and agility. For better service, AR focuses business revolution, organizational learning, process creation, integrated marketing and customer satisfaction. It has been successful with its own brand as well as with several licensed well-known international brands in the Taiwanese footwear market. Currently, AR group has more than 2,000 sales points in its distribution network. More than 200 new footwear products for all age groups, including sports, kids, leisure shoes, are introduced onto the market every season to catch up with world fashion trends and satisfy diverse customer needs.

\section{TP Co.}

TP is one of the popular private sportswear and casual wear manufacturing companies in Taiwan. Since 1997, it has provided a wide variety of stylish sportswear, casual wear and other accessories for young consumers and sports lovers. TP has grown rapidly in the past few years and now introduce new 
Table 1. Profiles of the Companies under Study

\begin{tabular}{|c|c|c|c|c|}
\hline Attribute & IM Co. & UD Co. & AR Co. & TP Co. \\
\hline Industry sector & Food products & $\begin{array}{l}\text { Book distribution and logistics } \\
\text { service }\end{array}$ & Sports footwear & Sportswear and fashionwear \\
\hline Years in business & $\begin{array}{l}75 \text { years } \\
\text { since } 1934\end{array}$ & $\begin{array}{l}30 \text { years } \\
\text { since } 1979\end{array}$ & $\begin{array}{l}20 \text { years } \\
\text { since } 1989\end{array}$ & $\begin{array}{l}12 \text { years } \\
\text { since } 1997\end{array}$ \\
\hline Reputation in industry & $\begin{array}{l}\text { A well-known, leading food } \\
\text { manufacturer }\end{array}$ & $\begin{array}{l}\text { The largest book distributor in } \\
\text { Taiwan }\end{array}$ & $\begin{array}{l}\text { Leading private brandin sports } \\
\text { footwear market }\end{array}$ & $\begin{array}{l}\text { Leading private brand in } \\
\text { sportswear market }\end{array}$ \\
\hline Supply chain echelon & Manufacturer and distributor & Publisher, distributor \& 3PL & Manufacturer and distributor & Manufacturer and distributor \\
\hline Return policy & No returns & $\begin{array}{l}\text { Full returns } \\
\text { (No returns only for special } \\
\text { deals) }\end{array}$ & $\begin{array}{l}\text { Full returns } \\
\text { (No returns only for special } \\
\text { deals) }\end{array}$ & $\begin{array}{l}\text { Full returns } \\
\text { (No returns only for special } \\
\text { deals) }\end{array}$ \\
\hline Marketing channels & $\begin{array}{l}\text { Company chain stores, local } \\
\text { distributors, hyper markets, } \\
\text { supermarkets, conventional } \\
\text { stores and convenience } \\
\text { stores }\end{array}$ & $\begin{array}{l}\text { Bookshops, chain } \\
\text { bookstoresconvenience } \\
\text { stores, Internet bookstores, } \\
\text { hyper markets, and } 3 \mathrm{C} \text { stores }\end{array}$ & $\begin{array}{l}\text { Sports specialty stores, shoes } \\
\text { shops, chain shoes stores and } \\
\text { department stores }\end{array}$ & $\begin{array}{l}\text { Company chain stores, sports } \\
\text { specialty stores, department } \\
\text { stores and general retail } \\
\text { shops }\end{array}$ \\
\hline
\end{tabular}

Note: Pseudonyms are used to protect the identity of the case companies

product lines for girls and kids. The channels of distribution include over 300 sports specialty stores, 47 direct selling stores, 41 franchise stores, and internet stores.

A summary of the profiles of four companies in the case studies is presented in Table 1.

\section{Findings From Case Studies and Discussion}

The results from the four case studies will be described in three parts. The first part reports the subject matter of the first six questions regarding reverse logistics activities. The second part will discuss initiatives in information technology, knowledge sharing and relationship networks in service innovation. The last part sums up the reverse logistics capabilities and competitive advantage of each case company.

\subsection{Returns Management and Reverse Logistics Capabilities}

The response to the six questions regarding the reverse logistics capabilities of the four case companies can be seen in Table 2. Further details are described below:

Figure 1: Process of Handling Product Returns at IM Co.

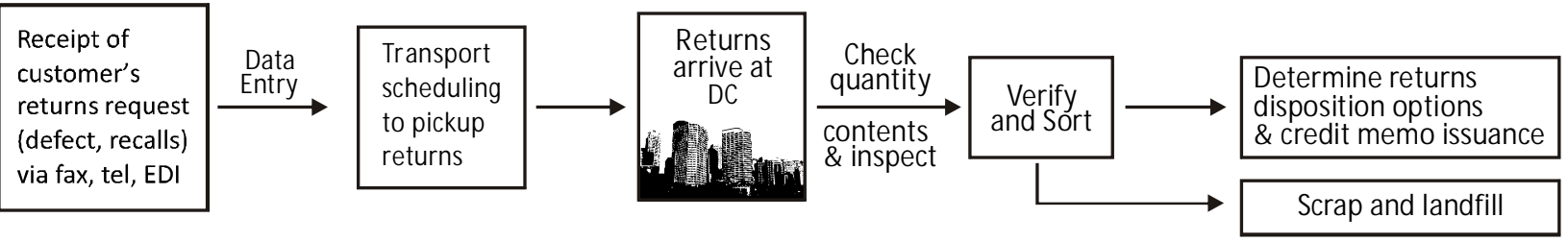

Note: Data entry includes customer ID, date of return, reasons of return, item number, item name and return quantity. 
Figure 2: Process of Handling Product Returns at UD Co.

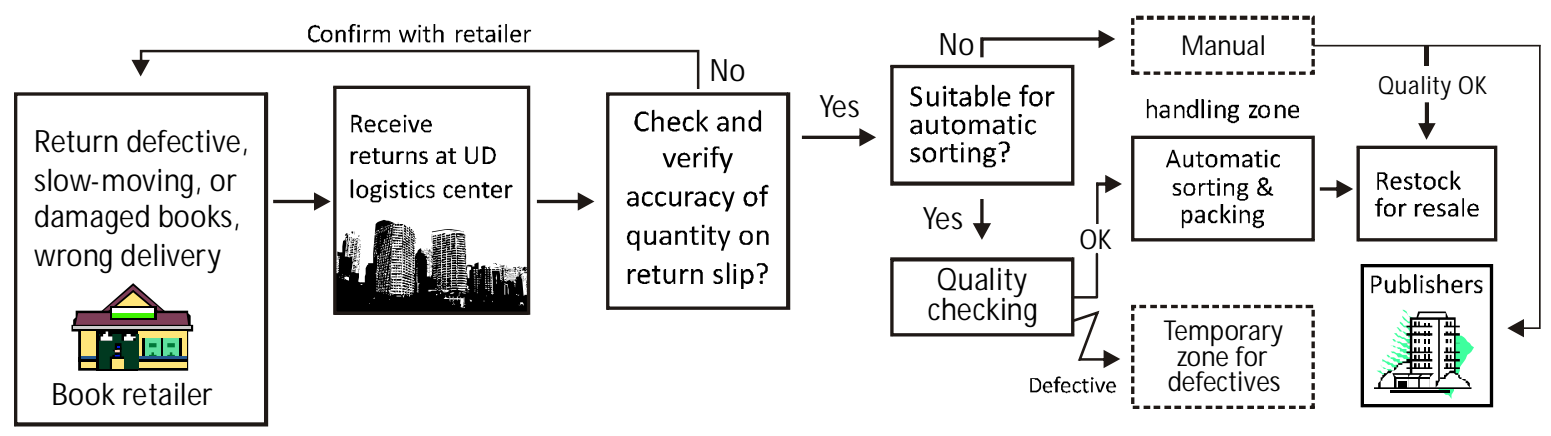

The sales agreement between IM and its customers is based on a no-return policy. Confined to defective items, product recalls, or pre-specified agreement, the return rate is very low and generally accounts for less than $1 \%$ of total sales. Though IM does not take back unsold items, it offers its distributors and retailers an allowance of $1.8 \%$ to $2 \%$ to compensate them for bearing the risk of unsold inventory. In practice, the retailers usually offer discounts before products reaching the expiry date in order to minimize wastes.

According to the field interview with the logistics manager, the process of handling returns at IM is shown in Figure 1. When the returns are received, the quantity of returns will be checked according to the returns note. If the quantity is correct, the returned products will be inspected and sorted into good products and rejected products. Rejected products, including expired or defective products, are disposed of as scrap. For good products, the length of reaching product expiry date and product conditions determine whether the products can be restocked for resale in the market, or sold to the secondary channels or off-price retailers. Then, the credit note is issued for the returns without questions, and customer account is also updated simultaneously. Generally speaking, the return process is managed quite efficiently at IM and normally takes about one day including credit processing.

The publishing industry annually produces about 40,000 new titles and over US $\$ 2$ billion in sales each year (GIO 2007). As a business practice, the publishing industry offers flexible returns policy that allows bookstore retailers to return books to publishers or distributors for full credit. The short lifecycle and the evolving internet bookstores, electronic books and magazines have raised the amount of returns and decreasing profitability to the supply chain. The return rate at bookstore levels averages over $50 \%$, and consequently, reverse logistics costs of distributors are increasing.

Though the discussion with the manager, the process of handling book returns at UD's logistics center was demonstrated in Figure 2. It should be noted that the credit justifications in customer account also automatically reflect in the customer's billing statement if the returns are finished processing by the $25^{\text {th }}$ day of each month.

Under current returns process, AR's retailer does not have to get the supplier's authorization in advance, so the retailer can return unwanted or excessive products at any time. As noted, the warehouse staff has to deal with incoming new products, outgoing customer orders and product returns. As a consequence, the large flows of unexpected returns can considerably increase workload and labor costs, affect manpower productivity, warehouse space efficiency, and reverse logistics costs at the warehouse.

As illustrated in Figure 3, the process of handling returns at AR's warehouse. For defective shoes, the surface of the shoes is destroyed, or the brand logo on the sportswear is cut under the supervision of the warehouse manager. Those shoes then are collected and stored in a designated place for a period of time. At last, they will be handled periodically by the environmental service company to dispose as scrap. All shoes or clothing scrap are photographed, and the scrap report is sent to the accounting department to write off the inventory of scrapped shoes or clothing. 
Figure 3: Process of Handling Returns at AR Co.

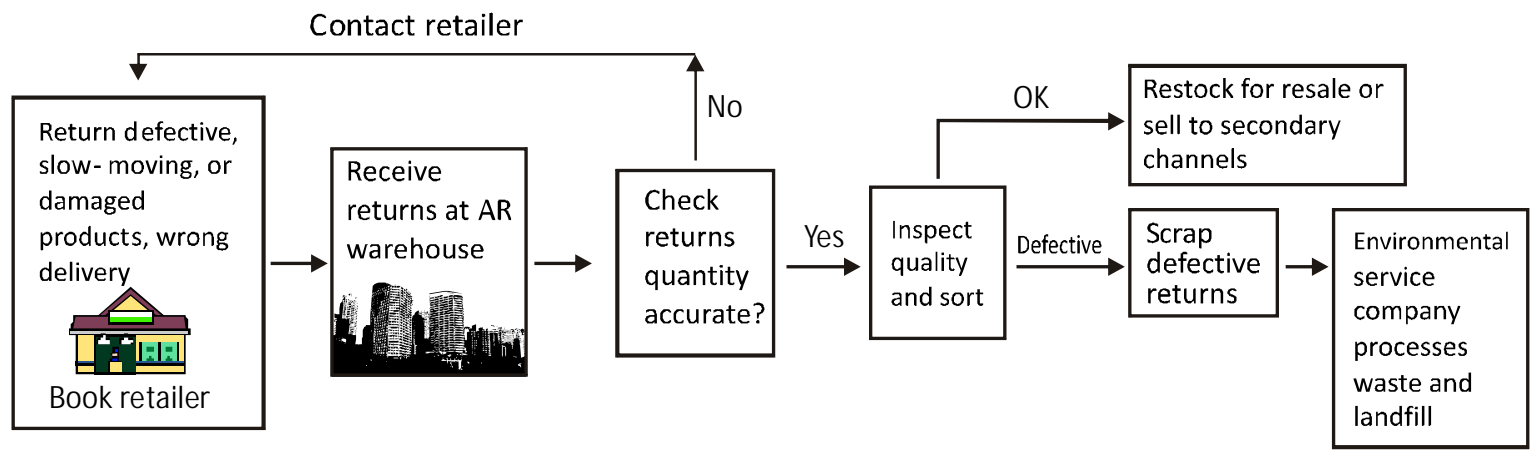

TP Co. currently has five brands for different target customers, including kids, young men, young ladies and working professionals, at low to medium prices. The return policy that TP has with general retailers can be either "full returns" at the end of each season or "no returns" for special deals, depending on the sales agreement. Most retailers choose "full returns" agreement to avoid the risks of carrying unsold inventory. Consequently, TP sustains a considerable volume of returns from different marketing channels at the end of each season. As shown in Figure 4, the process of handling returns of sportswear at TP is similar to that of AR Co. But TP has to quickly respond to the market performance as the seasonality involves a complexity of styles, colors and sizes for each sportswear item. Generally, it is required to report to accounting department when they write off the value of inventory.

Figure 4: Process of Handling Returns at TP Co.

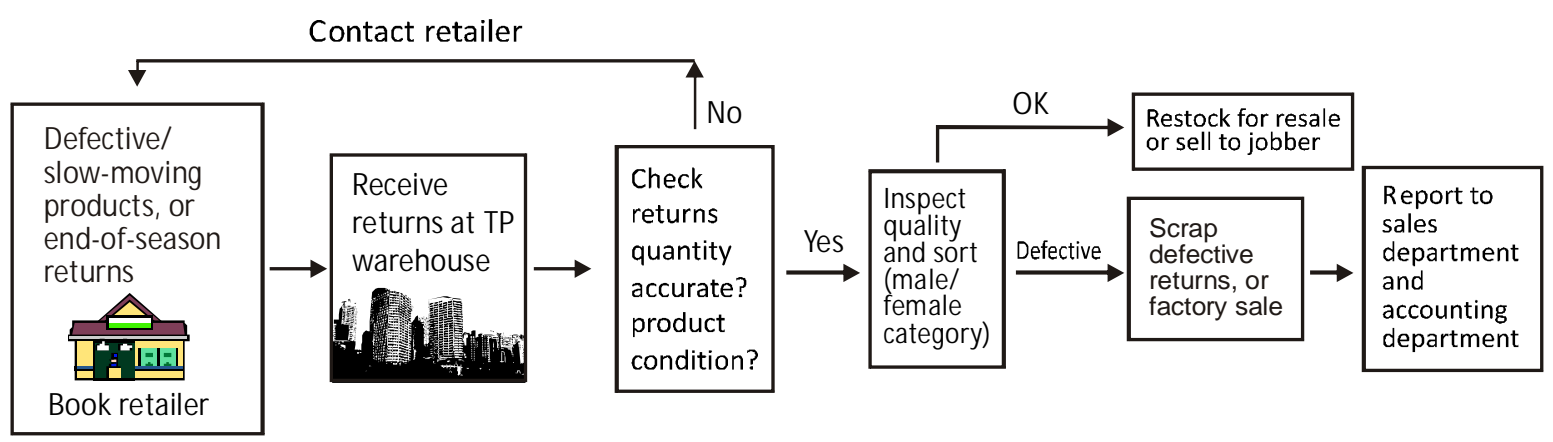

\subsection{Influence of Information Technology on Reverse Logistics Capabilities}

All IM's factories are equipped with modern facilities and reach international standards in food safety and hygiene, production facilities, storage and waste management. Its innovative technology and manufacturing process has allowed IM to achieve certifications for HACCP (Hazard Analysis Critical Control Point), GMP (Good Manufacturing Practice), CAS (Certified Agricultural Standards) and AIB (American Institute of Baking). IT process such as an order picking system, transportation scheduling and warehouse management systems enable IM's logistics center to perform efficiently in terms of warehouse efficiency, order cycle time, order fulfillment, real-time inventory status and returns 
Table 2. Summary of Interview Results $(Q 1 \sim Q 6)$

\begin{tabular}{|c|c|c|c|c|}
\hline Question & IM Co. & UD Co. & AR Co. & TP Co. \\
\hline $\begin{array}{l}\text { 1. Common reasons } \\
\text { for returns }\end{array}$ & $\begin{array}{l}\text { Defective items, product } \\
\text { recalls, inventory reposition or } \\
\text { pre-specified agreement }\end{array}$ & $\begin{array}{l}\text { Defective, slow-moving, or } \\
\text { damaged products, wrong } \\
\text { delivery }\end{array}$ & $\begin{array}{l}\text { Defective, slow-moving, or } \\
\text { damaged products, wrong } \\
\text { delivery }\end{array}$ & $\begin{array}{l}\text { Defective, slow-moving, or } \\
\text { damaged products, wrong } \\
\text { delivery, end-season returns }\end{array}$ \\
\hline $\begin{array}{l}\text { 2. Percentage of } \\
\text { product return }\end{array}$ & less than $1 \%$ of total sale & $\pm 50 \%$ of total sales & $30 \sim 40 \%$ of total sales & $30 \sim 40 \%$ of total sales \\
\hline $\begin{array}{l}\text { 3. Cycle time of } \\
\text { returns processing }\end{array}$ & 1 day & 1 3days & 1 3days & 1 3days \\
\hline $\begin{array}{l}\text { 4. Process of } \\
\text { handling returns }\end{array}$ & $\begin{array}{l}\text { Return request } \rightarrow \text { Authorization } \\
\rightarrow \text { Transport scheduling } \rightarrow \\
\text { Return collection } \rightarrow \text { Screening } \\
\text { inspection/sorting } \rightarrow \\
\text { Processing } \rightarrow \text { Stocking or } \\
\text { scrapping }\end{array}$ & $\begin{array}{l}\text { Receiving returns } \rightarrow \\
\text { Screening/inspection/sorting } \\
\rightarrow \text { Processing } \rightarrow \text { Stocking or } \\
\text { existing }\end{array}$ & $\begin{array}{l}\text { Receiving returns } \rightarrow \\
\text { Screening } \rightarrow \text { Inspection/ } \\
\text { sorting } \rightarrow \text { Processing } \\
\text { Stocking or scrapping }\end{array}$ & $\begin{array}{l}\text { Receiving returns } \rightarrow \\
\text { Screening } \rightarrow \text { Inspection/ } \\
\text { sorting } \rightarrow \text { Processing } \rightarrow \\
\text { Stocking or scrapping }\end{array}$ \\
\hline $\begin{array}{l}\text { 4. Process of } \\
\text { handling returns }\end{array}$ & $\begin{array}{l}\text { Return request } \rightarrow \text { Authorization } \\
\rightarrow \text { Transport scheduling } \rightarrow \\
\text { Return collection } \rightarrow \text { Screening } \\
\text { inspection/sorting } \rightarrow \\
\text { Processing } \rightarrow \text { Stocking or } \\
\text { scrapping }\end{array}$ & $\begin{array}{l}\text { Receiving returns } \rightarrow \\
\text { Screening/inspection/sorting } \\
\rightarrow \text { Processing } \rightarrow \text { Stocking or } \\
\text { existing }\end{array}$ & $\begin{array}{l}\text { Receiving returns } \rightarrow \\
\text { Screening } \rightarrow \text { Inspection/ } \\
\text { sorting } \rightarrow \text { Processing } \\
\text { Stocking or scrapping }\end{array}$ & $\begin{array}{l}\text { Receiving returns } \rightarrow \\
\text { Screening } \rightarrow \text { Inspection/ } \\
\text { sorting } \rightarrow \text { Processing } \rightarrow \\
\text { Stocking or scrapping }\end{array}$ \\
\hline $\begin{array}{l}\text { 5. Guidelines for } \\
\text { returns avoidance } \\
\text { and gatekeeping }\end{array}$ & $\begin{array}{l}\text { * Advance authorization of a } \\
\text { return request is required } \\
\text { * Emphasize high standard of } \\
\text { food materials and quality } \\
\text { assurance in manufacturing } \\
\text { to ensure product quality } \\
\text { and avoid unnecessary } \\
\text { returns }\end{array}$ & $\begin{array}{l}\text { * No advance authorization of } \\
\text { a return request is required } \\
\text { * Emphasize improved order } \\
\text { entry, order fulfillment } \\
\text { efficiencies, monthly } \\
\text { physical inventory check, } \\
\text { cooperative sales } \\
\text { promotion to minimize } \\
\text { returns } \\
\text { * Physical screening process } \\
\text { of return books is } \\
\text { performed at UD's logistics } \\
\text { center after receipt of } \\
\text { returns. *No advance } \\
\text { authorization of a return } \\
\text { request is required }\end{array}$ & $\begin{array}{l}\text { * No advance authorization of } \\
\text { a return request is required } \\
\text { * Emphasize monthly } \\
\text { physical inventory check at } \\
\text { the retail stores to avoid } \\
\text { excess inventory and } \\
\text { monitor each retail store's } \\
\text { sales performance } \\
\text { * Physical screening process } \\
\text { of return products is } \\
\text { performed at AR's } \\
\text { warehouse after receipt of } \\
\text { returns }\end{array}$ & $\begin{array}{l}\text { * No advance authorization of } \\
\text { a return request is required } \\
\text { * Emphasize efficient order } \\
\text { fulfillment, planned product } \\
\text { assortments, inventory } \\
\text { reposition or markdown } \\
\text { according to product life } \\
\text { cycles or sales } \\
\text { performance to reduce } \\
\text { returns at end of season } \\
\text { * Physical screening process } \\
\text { of return products is } \\
\text { performed at TP's } \\
\text { warehouse after receipt of } \\
\text { returns }\end{array}$ \\
\hline $\begin{array}{l}\text { 5. Disposition of } \\
\text { returns }\end{array}$ & $\begin{array}{l}\text { * Good, unexpired products } \\
\text { Restock for resale, sell to } \\
\text { secondary channels, or } \\
\text { offer employee benefits } \\
\text { * Defective products } \rightarrow \text { Scrap } \\
\text { and landfill }\end{array}$ & $\begin{array}{l}\text { * Good books } \rightarrow \text { Restock for } \\
\text { resale or return to } \\
\text { publishers } \\
\text { * } \text { Defective/damaged books } \\
\text { or out-of-date magazine } \rightarrow \\
\text { Return to publishers }\end{array}$ & $\begin{array}{l}\text { * Good products } \rightarrow \text { Restock } \\
\text { for resale or sell through } \\
\text { outlets or brokers } \\
\text { * Defective products } \rightarrow \\
\text { Destroyed and scrap } \rightarrow \\
\text { Environmental service } \\
\text { company handles waste } \\
\text { and landfill to ensure } \\
\text { quality brand image }\end{array}$ & $\begin{array}{l}\text { * Good products } \rightarrow \text { Restock } \\
\text { for resale or sell through } \\
\text { brokers, periodical sales } \\
\text { promotion, factory sales, } \\
\text { offer employee benefits, or } \\
\text { donation to charity } \\
\text { * Defective products } \rightarrow \text { Scrap } \\
\text { to ensure quality brand } \\
\text { image }\end{array}$ \\
\hline
\end{tabular}


processing. However, there is no integrated information system to connect the manufacturing unit, marketing unit and logistics unit as they work independently.

UD's logistics center is equipped with several leading-edge logistics facilities such as an automatic sorter. UD recently implemented an electronic board to show the completion rate and the NG rate of order-picking and returns processing including books and magazines at each shift. This application provides improved processing capabilities, greater operating efficiencies, and increased visibility of individual productivity as well as team productivity. All returned books and magazines are completely processed in 72 hours. At UD, the manpower productivity and error rate are key performance indicators used as a monthly evaluation of individual performance and salary assessment. Additionally, UD uses Enterprise resource planning (ERP) systems to monitor procurement, orders, schedules, inventory, and other information throughout the entire organization. An integrated third-party logistics information system offers access for UD's contract publishers.

Though the AR management has invested much effort in IT such as ERP systems and a warehouse management system, monitoring fast-changing consumer demands is still a tough challenge. To minimize the returns of unwanted products or excess inventory, AR's sales representatives perform physical inventory checking in their monthly sales visit to the retail stores. The logistics manager of AR stated that "the information flow and the coordination between the marketing department and sales representatives could affect the reverse logistics efficiency, especially in returns handling." Because a high return rate is inherent in a liberal returns policy, the marketing department has to closely monitor the inventory level of each product category and make quick decisions in response to the inventory information provided by the logistics department.

The logistics facility that TP has is not very complicated and includes order picking, racking, pallet truck and lift truck. The order picking and returns processing are based on manual operations, and no barcode inventory terminal is adopted to perform inventory checking. Therefore, the efficiency of warehouse operations and manpower productivity sometimes suffer. A customized business information system was developed to manage its order processing, inventory and purchasing management, accounting, reporting, etc. From the monthly reporting, an analysis of each retailer's sales performance and reasons for product returns help the sales representative to offer an appropriate product mix for each retailer in the selling season, so returns that occur at the end of season are not heavy.

\section{Section summary:}

From the results of four case studies, it can be seen that IT plays an important role, particularly in reverse logistics operations for short life-cycle products. For example, UD uses modern IT applications and an automatic sorter to process the high volume of book returns. IT facilitates efficiency in returns processing, recovery of product value and timing of re-reselling in the market and disposition decisions. Effectively using the IT-based resources to drive innovative solutions to returns management is critical to a firm's reverse logistics capabilities. As a result, the following proposition is suggested:

P1: A firm's innovative effort in information technology adoption can positively contribute to the enhancement of its reverse logistics capabilities.

\subsection{Influence of Knowledge Sharing on Reverse Logistics Capabilities}

IM has put great effort into ensuring environmental concerns are part of its corporate social responsibility, including producing green products and recycling. A clear description of the food safety and health issues are able to be shared with downstream customers and consumers. This is particularly important since the incident of melamine-contaminated milk power from China occurred in 2008 which panicked many consumers. Through IM's chain stores, it is easy for them to gather demand information and consumer preferences and response toward its food products. Accumulated customer knowledge enables IM to make better demand forecasting, manufacturing scheduling and inventory decisions. Thus, less product return occurs. The logistics manager of IM pointed out "information sharing is a critical source to enhance customer trust and loyalty to IM products" 
The website of UD provides retailers with the details of newly released titles, ranking of hot selling books and searching functions. It helps retailers to have better knowledge of the books or magazines they are selling and to make better purchase decisions.. Because the book return rate is high at bookstores, UD has to bear increasing reverse logistics costs. To minimize stockout or overstock, UD's sales representatives have to know what categories of books are suitable for which bookstore and what should be avoided. Moreover, information from return analysis can alert the company to identify problems and market demands. Returned books can offer insights about merchandising effectiveness and reader's expectations toward content design.

AR's sales representatives normally make a monthly sales visit to each retailer's store. During the sales visit, they are able to gather the voice of the retailers and sales records and collect defective returns or sales returns. They share the information with the marketing department. In accordance with the sales and inventory information, the marketing department can take quick actions to handle slowmoving products or adjust excessive stock at certain retail stores. Furthermore, the feedback from consumers regarding the physical attributes of shoes such as quality, functionality, durability, reliability, style, and packing can be valuable guidelines for future product designs and improvements.

With advanced technology in textile manufacturing, more and more eco-friendly textiles, Nano-textiles and functional fabric are now used in sportswear. To give the retailers and their sales clerks sound knowledge of the fashion trends, sports events, features and functions of the innovative fabrics used in sportswear is important in retail selling. Likewise, the retailers are able to provide feedback about customers' experiences or comments on the products and share customer knowledge with the supplier. In this way, TP can make improvements in future apparel designs and minimize unnecessary returns.

\section{Section summary:}

The demand for short life-cycle products is usually difficult to forecast. The shelf life of a book or a pair of sports shoes can be as short as two weeks. If the features of a product are not shared or information is not available for customers, this increases the possibility of unnecessary product returns. Sharing knowledge of product quality, feedback from customer experience, and insights of product returns is vital to not only improve the product or service designs, but also increase a firm's reverse logistics capabilities. Therefore, it is proposed:

P2: A firm's innovative effort in knowledge sharing can positively contribute to the enhancement of a firm's reverse logistics capabilities.

\subsection{Influence of Relationship networks on Reverse Logistics Capabilities}

It should be noted that IM's no-return policy impacts on its customers' purchasing in terms of replenishment quantity and try outs of new products. However, IM offers their distributors and retailers an allowance of $1.8 \%$ to $2 \%$ to compensate them for bearing the risk of unsold inventory. Moreover, IM produces various quantity packages with different prices to differentiate their products to avoid channel conflicts, To efficiently manage demand and avoid overstocking at the retail shelves, IM's sales representatives try to have a good understanding of customer needs and communicate well with each retailer. In addition, the sales information and inventory level of slow-moving products is transparent so decisions to transfer them to other chain stores can be made quickly.

In order to manage the high return rate in the publishing industry, UD implemented an innovative collaborative planning, forecasting and replenishment (CPFR) program in 2007. The main objectives were to collaborate with UD's upstream publishers and downstream retailers within its relationship networks, have a better forecasting mechanism, synchronize supply and demand and provide real-time information. In this way, they are able to effectively share resources, minimize inventory, reduce loss sales and plan reprint or publishing work. According to the president of UD, the logistics performance has been continuously improved, including reduced operational costs, increased visibility of inventory levels, and decreased inventory and return rate. More importantly, trust in the relationship networks facilitates continuous innovation in UD's logistics service offering. 
To reduce the amount of returns and reverse logistics costs, the sales representatives of AR have frequent communication with retailers and understand their demands. With good knowledge of customer preferences and sales performance, the mismatch of supply and demand, unnecessary returns, and excess inventory decreases. Advance notice of returns helps the warehouse staff do better warehousing plans and inventory control.

Relationship networks connecting customers from different marketing channels affect the motivation of service innovation. Frequent and effective communication is important to maintain good business relationships with retailers within their business networks. To avoid backlog or delay in the logistics operations, TP recently started to suggest retailers place replenishment orders and send back return sportswear on different days of the week. In this way, TP is able to coordinate its resources to improve performance and better serve its customers.

\section{Section summary:}

The four case companies all have multiple marketing channels, brands and different returns policy for different customer groups. Any innovative ideas, products, services or processes usually come up from the relationship networks. Panayides (2006) reports that relationship orientation can positively result in the improvement of the logistics service quality. From the survey results, it was found that more upfront communication within and across companies, responsiveness to customer needs and flexibility to market change can result in less product damages/returns back to the warehouse and better efficiency and cost-saving in reverse logistics operations. Therefore, it is proposed:

P3: A firm's innovative effort in relationship networks can positively contribute to the enhancement of a firm's reverse logistics capabilities.

\subsection{The Impact of Reverse Logistics Capabilities on Competitive Advantage}

IM Co. emphasizes high standards of food materials and quality assurance in manufacturing processes to enhance product quality and thus avoid the possibility of defects or returns. It gains competitive advantage in corporation reputation, customer loyalty and profitability. The use of modern logistics facilities enables UD to expedite not only the efficiencies of order fulfillment, but also the cycle time of processing a large volume of book/magazine returns. This allows UD to achieve competitive advantages in lower costs in reverse logistics and reliable order delivery in the publishing industry.

Nowadays, sports shoes and sportswear are very fashion oriented. The time from market to markdown and the time to respond to slow-moving products can significantly impact the firm's reverse logistics capabilities. Both AR and TP have to face the same situation. The longer it takes to process a returned product and make disposition decisions, the more inventory piles up and the tighter the cash flow. The relationship between sales representatives and retailers and their sales employees is crucial to the success of sales and product management. According to the warehouse managers of AR and TP, efficiency in returns handling and reverse logistics operations would be improved if the sales representatives were able to provide the right mix of products and support that the retail store needs through good communication. Thus, responsiveness to target markets and relationship building are major competitive advantages of AR and TP.

\section{Section summary:}

The case studies show that the four companies had different focuses on their reverse logistics capabilities due to variations in business scope and target customers. Their primary goal is to achieve competitive advantage in either lower cost or differentiation. Reverse logistics capabilities are more demand-oriented, with an emphasis on customer service, delivery reliability, delivery speed, relationship building and responsiveness to target markets. This leads to the following proposition:

P4: The reverse logistics capabilities of a firm can positively impact its competitive advantage

\section{Conclusion}

More liberal returns policies, changing customer demand and shorter product lifecycles often result in more product returns. How to effectively manage 
product returns, avoid waste and reduce unnecessary reverse logistics costs is a priority task for business firms in the face of current global economic turmoil. The reverse logistics literature indicates that effective returns management can be a marketable asset and achieve sustainable competitive advantage. Thus, this study aimed to understand how firms handle their returns processes and to investigate the relationships between reverse logistics capabilities and competitive advantage for short life-cycle products.

The results of the case studies indicated that a firm can enhance its performance by using relationships, IT and accumulated knowledge to differentiate itself on reverse logistics capabilities. As suggested by Stock et al. (2006), if the returns process for short life-cycle products can be performed in an efficient way, fewer products can escape destruction or markdown. In addition, it minimizes the loss of product value or timing of reentering into the market. Better disposition of returned items also can reduce logistics costs and better revenues.

To minimize excess inventory and unnecessary returns, a well-constructed communication platform is crucial for the smooth and rapid flow of information between departments and across companies. Insights gained from the returned products such as product effectiveness and consumer expectations can be shared between exchange partners in the relationship networks. The knowledge management will help the manufacturer in future product designs, improvements in customer service, or reductions in returns. Through the relationship networks, the firm can innovatively use its resource to lift up its reverse logistics capabilities and achieve competitive advantage.

This study contributes to a better understanding of reverse logistics operations for short life-cycle products and to provide a theoretical foundation of service innovation in reverse logistics capabilities. A firm's must continually and innovatively upgrade its capabilities to accommodate the changing needs of customers and to build sustainable supply chain management. However, to what extent how a firm's innovative service efforts can affect its reverse logistics capabilities and competitive advantage, there is a need to empirically test the four propositions developed here in future research.

\section{References}

Autry, C. W., Daugherty, P. J. and Richey, R. G. (2001). The challenge of reverse logistics in catalog retailing. Internal Journal of Physical and Distribution \& Logistics Management, 30 (1), pp. 26-37.

Fawcett, S. E., Stanley, L. L. and Smith, S. R. (1997), Developing a logistics capability to improve the performance of international operations, Journal of Business Logistics, 18 (2), pp. 101-27.

Ganesan, S., George, M., Jap, S., Palmatier, R. W. and Weitz, B. (2009). Supply chain management and retailer performance: Emerging trends, issues, and implications for research and practice. Journal of Retailing, 85 (1), pp. 84-94.

GIO (2007) Taiwan publishers marketing survey, Taipei, Government Information Office, Taiwan.

Global Logistics Research Team at Michigan State University (1995). World class logistics: The challenge of managing change, Oak Brook, IL, Council of Logistics Management.

Goffin, K. and Perkins, C. (2009) The recession: An innovation opportunity, Cranfield, UK, Cranfield University.

Grant, R. M. (1991). The resource-based theory of competitive advantage: Implication for strategy formulation. California Management Review, 33 (3), pp. 114-135.

Inkpen, A. C. (1996). Creating knowledge through collaboration. California Management Review, 39 (1), pp. 123-140.

Jack, E. P., Powers, T. L. and Skinner, L. (2010). Reverse logistics capabilities: Antecedents and cost savings. International Journal of Physical and Distribution $\mathcal{E}$ Logistics Management, 40 (3), pp. 228-246.

Jayaraman, V. and Luo, Y. (2007). Creating competitive advantages through new value creation: A reverse logistics perspective. Academy of Management Perspectives, May, pp. 56-73.

Kahn, K. B., Maltz, E. N. and Mentzer, J. T. (2006). Demand collaboration: Effects on knowledge creation, relationships, and supply chain performance. Journal of Business Logistics, 27 (2), pp. 191-221.

Kandampully, J. (2002). Innovation as the core competency of a service organization: The role of technology, knowledge and networks. European Journal of Innovation Management, 5 (1), pp. 18-26.

Kathuria, R. (2000). Competitive priorities and managerial performance: A taxonomy of small manufacturers. Journal of Operations Management, 18 (6), pp. 627-641.

Molenkopf, D. A. and Closs, D. J. (2005). The hidden value in reverse logistics. Supply Chain Management Review, July/August, pp. 34-43. 
Morash, E. A., Dröge, C. L.M. and Vickery, S. K. (1996), Strategic logistics capabilities for competitive advantage and firm success, Journal of Business Logistics, 17 (1), pp. 1-22.

Oliver, C. (1997). Sustainable competitive advantage: Combining institutional and resource-based view. Strategic Management Journal, 18 (9), pp. 697-713.

Panayides, P. (2006). Enhancing innovation capability through relationship management and implications for performance. European Journal of Innovation Management, 9 (4), pp. 466-483.

Pollock, B. (2010) Reverse logistics: Driving improved returns directly to the bottom line, Ashland, MA, Aberdeen Group.

Porter, M. E. (1998). On competition, Boston, Harvard Business School Press.

Richey, R. G., Genchev, S. E. and Daugherty, P. J. (2005). The role of resource commitment and innovation in reverse logistics performance. International Journal of Physical and Distribution E Logistics Management, 35 (4), pp. 233-257.

Richey, R. G., Tokman, M. and Skinner, L. R. (2008). Exploring collaborative technology utilization in retailer-supplier performance. Journal of Business Research, 61, pp. 842-849.

Rogers, D. S. and Tibben-Lembke, R. S. (1999). Going backwards: Reverse logistics trends and practices, Pittsburgh, PA, Reverse Logistics Executive Council.

Rogers, D. S. and Tibben-Lembke, R. S. (2001). An examination of reverse logistics practices. Journal of Business Logistics, 22 (2), pp. 129-148.

Soosay, C. A., Hyland, P. W. and Ferrer, M. (2008). Supply chain collaboration: Capabilities for continuous innovation. Supply Chain Management: An International Journal, 13 (2), pp. 160-169.

Srivastava, S. K. and Srivastava, R. K. (2006). Managing product returns for reverse logistics. International
Journal of Physical and Distribution $\mathcal{E}$ Logistics Management, 36 (7), pp. 524-546.

Stock, J. R. (2001). The seven deadly sins of reverse logistics. Material Handling Management, 56 (3), pp. 511.

Stock, J. R., Speh, T. and Shear, H. (2006). Managing product returns for competitive advantage. MIT Sloan Management Review, 48 (1), pp. 52-76.

Stock, J. R., Speh, T. W. and Shear, H. W. (2002). Many happy (product) returns. Harvard Business Review, 80 (7), pp. 16-17.

Stuart, J. A., Bonawi-tan, W., Loehr, S. and Gates, J. (2005). Reducing costs through improved returns processing. International Journal of Physical and Distribution $\mathcal{E}$ Logistics Management, 35 (7), pp. 468-480.

Swink, M. (2006). Building collaborative innovative capability. Research Technology Management, 49 (2), pp. 37-48.

Yang, C., Marlow, P. B., and Lu, C. (2009), Assessing resources, logistics service capabilities, innovation capabilities and the performance of container shipping services in Taiwan, International Journal of Production Economics, 122 (1), pp. 4-20.

Yin, R. K. (1994). Case study research: Design and methods, Thousand Oaks, California, Sage Publications, Inc.

Zhao, M., Dröge C., and Stank P. T. (2001), The effects of logistics capabilities of firm performance: Customerfocused versus information-focused capabilities, Journal of Business Logistics, 2 (2), pp. 91-107.

Ju-Miao Melody Hsiao is an Associate Professor in the Department of Marketing and Logistics Management, School of Management, Ling Tung University, Taiwan. She received a Ph. D. from Institute of Transport and Logistics Management at The University of Sydney in 2006. In the past two years, she has initiated several cooperative projects with industrial companies in Taiwan in the areas of third-party logistics, customer relationship management and internet marketing. Her teaching and research interests include supply chain management, customer relationship management, and marketing management. 